Scepticism, Animal Rationality and the Fortune of Chrysippus' Dog.

"For one can hardly deny that mankind has a common store of thoughts which is transmitted from one generation to another."

\title{
Gottlob Frege ${ }^{1}$
}

\section{$\underline{\text { Prologue }}$}

If Sherlock Holmes had carried out his "plan of writing a small monograph upon the uses of dogs in the work of the detective", ${ }^{2}$ he might have devoted a brief chapter to the only episode, in his adventures, in which his investigative mind required the help of Pompey, "the pride of the local draghounds" ${ }^{\prime 3}$. Without him, Holmes would have never been able to trace the carriage of Dr Armstrong, and thus solve the case in The Adventure of the Missing Quarter. For once, the master of logical inferences had to acknowledge the superiority of a dog's nose. This is an old story, of course, and things have been more intricate in the history of thought than Holmes could have realised. 


\section{$\underline{1 . " H i s ~ d o g, ~ W a t s o n, ~ d o e s ~ t h a t ~ s u g g e s t ~ n o t h i n g ~ t o ~ y o u ? ~}{ }^{14}$}

Before the industrial revolution and the subsequent development of crime stories, ${ }^{5}$ hunting provided the most common family of images and metaphors to describe intellectual investigation, something that, for obvious sociological reasons, has become less popular nowadays. Hume thought that "there couldn't be two passions more nearly resembling each other, than those of hunting and philosophy, whatever disproportion may at first sight appear betwixt them". ${ }^{6}$ And according to Cesare Ripa, ${ }^{7}$ the symbolic iconology of 'Investigazione' should include, among other details, a dog nosing after a prey. In order to exemplify such an image, the painter was expected to draw a "Woman with a winged head [...] who is pointing with her left forefinger to a dog, which is nosing after a prey. The wings mean the elevation of the intellect, which by raising itself comes to know the highest and most celestial things. About the meaning of the Dog, the Pyrrhonian philosopher Sextus, in the first book, chap. 14 [of the Outlines, my note], says that it denotes investigation, because, after having chased an animal, reached a place where three streets meet, and having missed which way the animal went, he smells at the first and at the second road, and if it does not scent that the animal went one or the other way, without further smelling he rushes off by the third, arguing that necessarily this must be the path followed by the prey". 8 As Ripa acknowledged, the figure of the inquisitive dog was not his own invention. The idea had already been used by Sextus Empiricus in the Outlines: "[Chrysippus] declares that the dog makes use of the fifth complex indemonstrable syllogism when, on arriving at a spot where three ways meet , this is a hapax legomenon in Sextus], after smelling at the two roads by which the quarry did not pass, he rushes off at once by the third without stopping to smell. For, says the old writer, the dog implicitly reasons thus: 'The animal went either by this road, or by that, or by the other: but it did not go by this or that, therefore he went the other way" ${ }^{\prime \prime}$. The works of Sextus Empiricus represent the most influential synthesis of sceptical arguments in the history of philosophy, and it is interesting to detect their influence on Cesare Ripa himself. Already known to Francesco Filelfo since the beginning of the fifteenth century, both the Outlines of Pyrrhonism and Against Mathematicians had some diffusion in the following decades, but they were edited for the first time, in Latin translation, only in 1562 and then in $1569 .{ }^{10}$ Only after those dates did the two texts have a more widespread impact on European culture. Hence, it is not surprising that the description of 'Investigazione' on a Pyrrhonian basis should appear only in 1613, in the fourth edition of the Iconologia. The fact that the Outlines turn out to 
be one of the sources of Ripa's fashionable work shows that, by the beginning of the new century, the Pyrrhonist author had finally become quite familiar reading. ${ }^{11}$

Sextus Empiricus used Chrysippus' dog within the context of "comparisons between mankind and the so-called irrational animals in respect of their sense-impressions", in order to illustrate the first of Aenesidemus' tropoi. The latter aimed at showing that "the same impressions are not produced by the same objects owing to the differences in animals". ${ }^{12}$ As usual, in order to undermine the exaggerated confidence in human cognitive capacities, shown by "those conceited braggarts", ${ }^{13}$ Sextus assembled a rather large collection of different arguments. His essential line of reasoning, however, can be reduced to the following points: (i) owing to their physical constitution, animals have different sense-impressions; (ii) because of such a diversity of sense-impressions, we must suspend judgement in regard to the nature of reality in itself; (iii) it would be pointless to reply that man is in a better position than any other animal to draw comparisons, and assess the reliability of the respective sense-impressions because: (a) man himself is closed within the inescapable boundaries of his own cognitive framework; and (b) as far as cognition is concerned, there are many cases in which animals reveal themselves to be plainly superior to man himself; it follows that (iv) animals having disparate perceptual experience, none of them enjoys a better grasp of the nature of things in themselves, and thus all we can do is to state how things appear to be to us in each case, advancing no claim on the real nature of what is in question. The episode of the dog occurs within the context of (iii.b). As often happens in his work, Sextus turns against the Stoics an example first formulated by the latter for different, if not opposite, purposes.

So much for the context within which the episode of the dog is recounted. If we concentrate now on the first edition of Ripa's Iconologia (1593), and check the last entry in the description of the iconography of 'Dubbio', we cannot fail to perceive a close similarity to Sextus Empiricus' contrast: "A naked and thoughtful man, who having reached a crossroad of two or perhaps three streets, appears confused, not knowing which way to go. [...] He is represented as naked in order to make explicit his irresolution"14. The fundamental clue in the iconography of 'Dubbio' is obviously Ripa's further specification that the roads may be three, rather than the usual two. The third road is thoroughly redundant, and apparently the logic of the description is not immediately explicable. There is a large number of representations of the homo viator in bivio,${ }^{15}$ and the literature on decisions to be taken at crossroads is equally ample, ${ }^{16}$ but the image of doubt is usually represented as a dichotomy, or a 
dilemma, between left or right, one or the other, good or bad, right or wrong. Hercules, for example, has to decide between two roads, ${ }^{17}$ while Freedom holds in her hands the letter 'Y', indicating the capacity of choosing between two options. Likewise, in his Mundus Symbolicus ${ }^{18}{ }^{\text {Picinelli symbolises }}$ 'Doubt' by means of a tree whose direction of fall we do not know (the source is Ovid, qua cadat, in dubio est), ${ }^{19}$ by means of a lover in doubt, or finally as the choice between right and wrong. The reference is the Virgilian verse discrimine secta bicorni. ${ }^{20}$ In English we speak of the horns of a dilemma, and even the etymology of dubium, and of the German equivalent Zweifel, reveals that uncertainty is to be understood as a Manichean tension between two alternatives. It seems that the image of the trivium as a symbol of doubt was an iconographic novelty. How did Ripa come to conceive of it? The suggestion that he was providing a rather elaborate, if correct, interpretation of the episode of the dog in the Outlines must be immediately discarded. Ripa was not an author interested in scepticism, nor could he be credited with a deep or original understanding of Sextus Empiricus' thought. Quite the opposite, he probably did not even perceive that there might be a connection between the two different behaviours of a man and of a dog standing at the same trivium. Besides, the suggestion that Sextus may have exercised a direct influence on the first edition of the Iconologia would imply that the Pyrrhonist was already something of a 'best-seller' in 1593, a possibility undermined by all our evidence. So the question remains: is there any connection between the two images of a man and a dog standing at the same trivium?

\section{2. "Someone has loosed the $\operatorname{dog}^{\text {"21 }}$}

The originality of the iconography of 'Dubbio' leads one to suspect that whatever Ripa's indirect source was, what made it possible to associate the idea of 'Dubbio' to the image of trivium in 1593 was also what lay behind the episode of Chrysippus' dog recounted in 1613, in connection with 'Investigazione'. It can hardly be a mere coincidence that the two beings are standing at a trivium, one hesitating in doubt, while the other discloses all its deductive capacities. One can start searching for an explanation by recalling that in ancient Greek to be at a trivium (en triodo) was used as an idiomatic expression to mean "to be in doubt". Of course this, of itself, would merely shift our problem several centuries backward, if it were not for a nice passage in which Theognis manifests his doubts about two styles of life: "I stand in a trivium: two are the roads in front of me $[\ldots]^{122}$. For a Greek of the sixth 
century $^{23}$ to be in doubt was indeed to be torn between two alternatives, but he expressed this situation more accurately as one of standing in a trivium, because he counted the two roads in front of himself as well as the one he came from. By the fifth century, "to be at a trivium" had already become a proverbial locution. Thus, Plato could write in the Laws: "Every young man, - not to speak of old men - on hearing or seeing anything unusual and strange, is likely to avoid jumping to a hasty and impulsive solution of his doubts about it, and to stand still; just as a man who has come to a crossroads ) and is not quite sure of his way, if he be travelling alone, will question himself, or if travelling with others, will question them too about the matter in doubt, and refuse to proceed until he has made sure by investigation of the direction of his path"24. The closeness of this passage to the iconography of 'Doubt' shows that Plato was most likely Ripa's literary source. Ripa's uncertainty was due to the fact that the young man is not standing at a trivium but, like Theognis, has reached it. The idea of movement leads one to presume that the person has come to a place where he then finds three further roads in front of him, not two and one behind, as Plato's text should probably be interpreted. ${ }^{25}$ Ripa was not quite sure how he should read the Platonic passage. This is why he wrote, rather equivocally, "having reached a crossroad of two or perhaps three streets".

The identification of the Greek roots of Ripa's figures solves our opening puzzle about the similarity between the iconology of 'Investigazione' and 'Dubbio', and suggests a further clarification. Suppose you were a Greek logician who wished to illustrate the following reasoning: either $\mathrm{p}_{1}, \mathrm{p}_{2}$, or $\mathrm{p}_{3}$, but not $\mathrm{p}_{1}$ and not $\mathrm{p}_{2}$, therefore $\mathrm{p}_{3}$. Obviously, you would interpret it as an ordinary tree-structure, in this case a trivium. Given the linguistic uses of the time, you would also be led to visualize the image of the doubtful man at a crossroads. As Plato indicates, however, it is difficult to establish how the human subject can decide among the alternatives. This is precisely why the trivium is a convincing representation of 'doubt'. So you would need someone with a superior capacity. The idea that the dog was endowed with "incredibilis ad investigandum sagacitas [...and] tanta alacritas in venando ${ }^{126}$ has been always very common in human culture, and the ancient world was not an exception, quite the opposite. ${ }^{27}$ According to Olympiodorus, Socrates used the oath "by the dog" because of the rationality of the animal, ${ }^{28}$ and Plato himself described the dog as a philosophical animal. ${ }^{29}$ A hunting dog who could decide in favour of a road by sniffing only the other two is precisely what would serve your purpose best. So you put the dog at the crossroads and make it a successful illustration of your 
syllogism. I suppose this was the mental process that led Chrysippus to elucidate what he meant by his fifth anapodeictic syllogism by means of the image of the friendly quadruped at a trivium. ${ }^{30}$ He had moved from the bivium-trivium as a symbol of radical doubt to the trivium as the obstacle that must be surmounted by an investigative mind.

\section{3. "You don't keep a dog?"131}

The structure of the inference presented by Chrysippus has been variously formalized ${ }^{32}$ but its meaning is clear, one would be tempted to say almost 'trivial'. As Sherlock Holmes would remark, "when you have excluded the impossible whatever remains, however improbable, must be the truth"33. And because of its simple and picturesque character, Chrysippus' nice analogy turned out to be the preface to a curious chapter in the history of thought. ${ }^{34}$ Although in the second century A.D. the Stoic Cleomedes could still use the "syllogism of the dog" in order to demonstrate that the earth is spherical, ${ }^{35}$ the syllogising dog became part of the alleged evidence discussed by several philosophers who endeavoured to understand whether animals have their share of intelligence, and if so, what this may involve. At the beginning of the Christian era, Philo of Alexandria wrote a dialogue ${ }^{36}$ in which he rebutted, among other things, the attempt to interpret the episode of the dog as a confirmation of the rationality of animals. Alexander, Philo's interlocutor, ${ }^{37}$ is made to formulate the example in a slightly different way. In this case, the hound comes to a deep shaft which has two trails beside it. After having tested both of them, "with no further scenting it jumped into the shaft to track down hastily". Alexander's nice refinement of the analogy admits no counter argument in terms of capacities of the dog to track the smell of the prey (see below what Plutarch has to say on the point), and yet it did not suffice to convince Philo. According to the latter, the episode of the dog had been unduly over-emphasized. It is a common fallacy to see more evidence in certain natural events than there really is. For Philo, the dog was simply endowed with a natural capacity, some kind of instinct. Only people overworried by sophistic arguments may be inclined to present his behaviour as the result of a capacity for reasoning, he wrote. One may add that Alexander's fallacy must have been quite tempting, if a philosopher of our time such as O'Connor has been led to commit it again. In a recent work, he has argued that since "the dog may evince without language his belief that he has a bone buried in the corner of the garden"138, and since a belief is bound to be true or false, it follows that the dog has to be credited with true or false beliefs. 
Philo objected that Alexander, and hence O'Connor as well, overlooked the important fact that it is only the observer who interprets the dog's behaviour in terms of beliefs as actual mental contents and inferences. Beliefs as 'believings', i. e. mental states or activities, are part of a behaviour and thus cannot be true or false, but perhaps justified, unsuccessful and so forth. If the dog were using the fifth syllogism - Philo continued - then all the people who search for something would always be using such an inference too, an obvious reductio ad absurdum according to him, since he presumed that everybody is aware of the fact that, when we search for something, we very rarely find it by performing an explicit heuristic procedure, let alone a syllogism.

In his objections against Alexander, Philo presented a standard anthropocentric perspective which soon became popular, and remained largely unaltered at least until the eighteenth century. The basis of his resistance was both theological and epistemological, his historical source, among others, the New Academy. In the first place, $\underline{\log o s}$ as rationality was taken to be the criterion (in a Wittgensteinian sense of the word, i. e. a discriminating feature) which distinguishes man from animals, since human intelligence is an image of God's nous. In the second place, brutes cannot speak, and this is an evident sign of their irrationality (in Greek this is expressed in terms of a-logicality i. e. 'absence of logos-word'). The noise animals make is similar to the sound produced by musical instruments, Philo maintained. Animals are a-rational, have no capacity of reflecting upon options, so cannot be assumed to be responsible for their actions, and cannot be virtuous or corrupt either. As a-rational beings, they have a precise position in the continuum of creation, existing for the sake of rational beings. Nature creates them well endowed with all the capacities they require to deal with their lives, as an artisan may construct a perfect instrument. As inferior beings, they are subject to man, who exercises full authority over them. Philo's combination of Stoic, Platonistic and Judaeo-biblical doctrines earned many followers in the following centuries. In his denial of the rationality of animals he was almost as extreme as Descartes, although his was not such a dualistic philosophy.

Because of the debate between Alexander and Philo, one is inclined to suspect that Chrysippus did not mean himself to be taken too literally. If one reflects upon the Stoics' adversion to the possibility that animals may be intelligent creatures endowed with 'logos', one ought to conclude that Chrysippus had few doctrinal reasons to present the dog as evidence in favour of the 'logicality' of brutes. In another context, for example, he is reported to have maintained that man has no ethical responsibility towards 
brutes since they are 'mindless'. ${ }^{39}$ The episode of the dog was probably to be interpreted not in itself, but as a rhetorical invention, at most a didactic contrivance with a merely expository aim. ${ }^{40}$ After all, according to Stoic cosmology brutes were related to man as the latter was to God, in a sort of ascending scale. The creation of a rational animals was providential and to the advantage of human beings, the only other rational animals apart from God. ${ }^{41}$

This broader context must be born in mind, if one wishes to understand Plutarch's twofold attack on the way Stoics deal with animals. On the one hand, he claimed that Chrysippus was ridiculous if he really believed that the dog was using any sort of "multiple disjunctive argument". A dog "does not need such testimonial, which is both false and fraudulent; for it is perception itself, by means of track and spoor, which indicates the way the creature fled; it does not bother with disjunctive and copulative propositions" ${ }^{\prime \prime 2}$. Since the dog does not find himself at a trivium abruptly, but has tracked the animal up to the trivium, he does not really need a syllogism in order to be able to hunt his prey successfully, for he could simply continue to pursue the traces he has been following until that moment, without facing any "trilemma" and hence the urgent need to formulate an inference. On the other hand, Plutarch defended the position of brutes in comparison to human beings. Animals are better than the Stoics presumed. They do not depend on silly logical contrivances in order to achieve their aims but, since they have perceptions, they enjoy a kind of natural reasonableness. It should be noted that the undeniable fact that brutes have perceptions, are able to learn from experience, and can memorise past events will ultimately represent a serious difficulty for all the most radical defenders of the irrationality of animals.

Two centuries later, Basil of Caesarea (c. A.D. 330-79) thought that there was a core of truth in what we have seen to be Plutarch's position. He did stress that the dog was not really intelligent, but he also added that it enjoyed a kind of sensibility which compensated for its shortcomings. The conclusion? "Whereas the wise of our world may spend a life-time of laborious meditation on the combinations of syllogisms, dogs manage to clear up such problems naturally. [...]. Thus by eliminating the erroneous alternatives, the dog discloses the truth. So do also those grave men of thought, who, seated in front of geometrical figures, draw lines in the sand and, confronted with three propositions, have to discard two in order to discover the truth of the one that remains" ${ }^{\prime \prime 3}$. Ambrose, who was influenced by Basil himself and probably by Philo as well, ${ }^{44}$ felt he might share the same opinion. Nobody doubted that the dog was not equipped with a real capacity to reason. The dog at the trivium 
was able to trace his prey simply by following his innate capacities and instinct, no matter whether philosophers and logicians could reconstruct and render explicit, a posteriori and with great labour, his natural inferences. ${ }^{45}$ The first centuries of the Christian era were definitely not the most favourable to our logical friend. No wonder, for the praise of the dog in general belonged to the Classical tradition, not the Hebraic, and in the metaphorical language of the Bible dogs never played a decent role. So those who intended to advocate his rational capacities needed to concentrate on the most congenial version of the episode, and follow Claudius Aelianus (c. A.D. 170-235), who had rejected the Stoic position in his De Natura Animalium by reminding the reader that: "[...] the dog came upon a ditch and was puzzled as to whether it [the hare] had better follow to the left or to the right. And when it seemed to have weighed the matter sufficiently, it leapt straight across. [...] The Hound [...] said to himself: 'The hare turned either in this direction or in that or went ahead. It turned neither in this direction not in that; therefore it went ahead" $^{\prime \prime 66}$.

Born around 232 A.D., almost the same year when Aelianus died, Porphyrius too was an earnest defender of the cause of the animals. It will be remembered that Philo rejected the possibility that brutes may be intelligent by pointing out the fact that they make noise but do not really speak. Philo did not have epistemological categories such as 'unconscious' 'subconscious' or 'subliminal' to multiply the levels of the activity of the self, but he could have spoken of 'silent speech'. ${ }^{47}$ If he did not, on that occasion, it was for equally obvious argumentative reasons, as was very clear to his antagonist Porphyrius. In his De Abstinentia, the latter emphasised that the Stoics had no apparent justification for denying to animals an internal capacity of reasoning with themselves. The same issue had been of central importance to Sextus Empiricus as well, to such a point that he had used it as the introduction to the paragraphs in which he spoke of Chrysippus' dog and other similar episodes. ${ }^{48}$ Both Sextus and Porphyrius began by restating the Stoic distinction between internal and external reason (internal and uttered $\underline{\log g s}$ ). The former is what we would properly call Reason, the latter Discourse or Speech, that is the capacity of verbalizing what is reasoned. Both of them then proceeded by arguing that the Stoics have no justification for denying the possibility that a dog may go through an internal process of reasoning. Judging from the appearances, all his behaviour points towards the opposite conclusion. Of course, once the door was open to the hypothesis of a successful, rational activity of a proto-linguistic nature, it was impossible to draw any limit to what brutes are capable of. Besides, the Stoics were 
already prepared to attribute to animals an external reason, an uttered $\underline{\log o s}$, in terms of noise. ${ }^{49}$ Porphyrius added several other objections to this first set, but the one which interests us here is the paradox in which he contended the Stoics were bound to collapse, when they denied any reasoning capacity to animals while at the same time portraying the dog at the trivium as drawing his conclusions on the basis of a complex disjunction. Again, all this reminds us of Sextus. Indeed, the line of Porphyrius' reasoning appears so close to that of Sextus that the latter may well have been a direct source for the entire series of arguments. ${ }^{50}$ Porphyrius' conclusion was equally 'Sextian': it is too easy for the Stoics to argue that the dog accomplishes what he does only because of a natural instinct. It has to be admitted that animals differ from men only in degrees. ${ }^{51}$

\section{4. "Dogs don't make mistakes"}

All the aforementioned authors presented the dog as going through the same procedure in a roughly identical situation. With the obvious exclusion of Chrysippus, none of them intended the episode as a defence of propositional logic. Such a shift of the image of the rational dog from logic to ethnology and epistemology may indicate what a hard life the diffusion of Aristotelian syllogistic gave to Stoic philosophy in antiquity. It certainly accounts for the fact that, once detached from its original explanatory function, the image of the dog at the trivium could easily be employed for other tasks. The logical animal could regain a definite dialectical value within the sceptical context of the Outlines, in which he was presented as a patent case of the rational behaviour of a brute being superior to that of man. But the fortune of Aristotelian logic and the disappearance of the Sceptical school during the Middle Ages did nothing to encourage people to keep the 'syllogising dog' within such a dialectical framework, no matter whether Stoic or sceptical. ${ }^{53}$ Thus, during the first half of the twelfth century, the author of De Bestis provided a very accurate version of the story - in which the dog actually makes a number of strict inferences and soundly concludes by saying to himself: "sic falsitate repudiata in veritatem prolabitur" but the context was that of a collection of notes and anecdotes concerning the animal world. Other similar works ${ }^{55}$ show the same tendency: no attention was paid either to the logic used by the animal or to the meaning of the fact that he could reason as well as, or even better than, any other human being. Since the ups and downs of the history of philosophy were so influential for the fate of our intelligent animal, evidently he had to wait for a revival either of Stoicism or of sceptical themes in order to 
reappear on the scene with a strong dialectical role. As it happens, scepticism came first. When the debate upon universals reached the level of a "fruitless logomachy", ${ }^{56}$ John of Salisbury took a stand as a defender of a very mild form of Ciceronian scepticism. The arrogance of reason, unaided by God, may be moderated by a sceptical distrust in the intellectual and cognitive power of man. ${ }^{57}$ Logical reasoning and sensation can be trusted to a degree, but we should not waste our time investigating the dubitabilia sapienti. Topics such as the nature of attrition, whether, if a person has a single virtue, he must possess all of them, or whether all the sins are equally serious, are among the many issues which do not admit of any definite answer. According to John, we would be better off by leaving them aside. And yet, our medieval philosopher did not mean to defend a radical form of scepticism. In his view, sceptics had overstated the extension and gravity of their doubts. If even animals can perceive properly, if even the dog is endowed with a certain capacity for rational thinking, how can we deny to man the possibility of knowing something? By listening too much to their doubts in all directions, sceptics cannot find the right way to happiness. Indeed, "sane ad patriam nemo pervenit, nisi qui unam sequitur viam", 58 and the latter is only the Ciceronian philosopher.

For his information about the rational dog, John was perhaps exploiting his acquaintance with the mediaeval Bestiari, ${ }^{59}$ but his use of the episode was completely different. Not only was he reviving the dialectical meaning of the reference to the intelligence of the animal, but in his presentation of the topic the roles were also inverted. It was now the sceptic who turned out to be at the trivium, not knowing where to go, whereas the rationality of the dog provided evidence in favour of a more 'dogmatic' approach to knowledge. One may doubt whether Sextus had not already disposed of such a reply. How do we know that the dog can smell better than us, or the camel remember more than we do? We seem to perceive this, but a rigorous position will allow us to maintain only a descriptive approach, the one suggested above by Sextus himself. The Pyrrhonist may have underlined that we are not allowed to assume an external, objective point of view, from which we then proceed to assess the value of the different perceptions enjoyed by different animals with respect to the underlying reality. John's slightly dogmatic interpretation of the rationality of animals appeared to succumb to the charge of circularity.

If John of Salisbury was possibly the first medieval philosopher to re-insert the alleged capacities of the hunting dog in a dialectical context, it was left to the following century to grant a bright 
future to the animal at the trivium. In the Summa, Thomas Aquinas presented the same story in its original version, giving it a very favourable twist. He held that the episode proved that animals too have the capacity of choosing. ${ }^{60}$ Although Aristotle had been much more cautious, ${ }^{61}$ scholastic philosophy was putting its imprimatur on Chrysippus' dog and the recognition of some kind of intelligence in brutes.

Humanistic culture represents a break with regard to Scholasticism in many respects, but as far as the role of the rational dog is concerned, an unbroken line links Thomas Aquinas' remarks and Petrarch's famous portrait in which there occurs a dog. The animal inhabits the representation of the humanist's study more and more commonly, as the symbol of fidelity to scholarly work, of sagacity, of perseverance, or even of the activity of reasoning or dialectics, as in a portrait of St Augustine. ${ }^{62}$ Sometime between 1480 and 1490 Martin Schongauer painted the Chasse Mystique, in which the Archangel Gabriel holds four dogs, representing misericordia, $\underline{\text { iustitia, }}$ pax and veritas. Years later, Reish used the same image in his Margarita Philosophica (1503), in order to illustrate the nature of Logic (pp. 38-39) symbolized by a hunting woman armed with a sword (yllogismus) and a bow (questio), who is blowing into a horn (sonus vox, which emits premisse) while she is following two dogs (veritas and falsitas) that are tracing a rabbit (problema). In 1514, Dürer felt it important to insert a very meditative dog in his Melancolia I, and was soon followed by the Cranach. ${ }^{63}$ The inquisitive character of the animal was obviously very popular, and the recognition of his peculiar intelligence had become common currency. No wonder, then, if in 1546 Rabelais believed it appropriate to open the first volume of Gargantua and Pantagruel $^{64}$ with a comparison between a dog and a reader. He suggested that in the same way as the dog bustles about a bone, breaks it into pieces and then eats the marrow, the reader may be willing to spend similar effort in searching for the best books. Once he has found them, he may open and study them, until he has absorbed the best nourishment for his mind. Expressing a prolific imagination, as well as a deep acquaintance with classical culture, Rabelais could combine together, very skilfully, several metaphors: the image of the rational dog, the presentation of the search for knowledge as a sort of hunting, the idea that books need to be munched like bones, and the equation between food as nourishment for the body on the one hand, and culture as sustenance for the mind on the other. ${ }^{65}$ Thanks to his talents, Rabelais succeeded in drawing a new, lively and light analogy. The same cannot be said about other similar efforts. In 1597 Jacopo Mazzoni published his In Universam Platonis et 
Aristotelis Philosophiam Preludia sive de Comparatione Platonis et Aristotelis. The work is a mine of information about past philosophy. A learned man himself, Mazzoni might have been acquainted with Ripa's iconology of 'Investigazione', or with some of the authors who had spoken about Chrysippus' dog. Perhaps he knew of Rabelais' metaphor. At any rate, he decided to begin his Dedicatio with a lengthy comparison between philosophy and the role of dogs in hunting. We have seen that the comparison between the search for knowledge and hunting for prey was an old rhetorical device. ${ }^{66}$ Probably the most influential example, closest in time to Mazzoni, had been Nicholas de Cusa's De

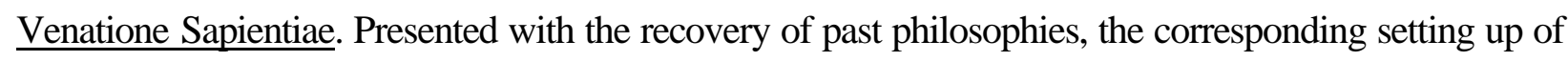
a pluralism of intellectual systems as well as with the need for the elaboration of philological tools on a level with such discoveries, Mazzoni wished to apply the image of the hunting dog to a deeply controversial issue, namely the clarification of the relationship between new and ancient philosophy. What he ended up with was a rather bizarre equation: in the same way as hunters need dogs in order to find the prey, so modern philosophers need Plato and Aristotle in order to orientate themselves in their search for wisdom. The ancients had to be our dogs. Mazzoni was perhaps a bit messy with analogies, but when it came to inferences he showed himself to be a consistent thinker. In all seriousness he reassured his reader that: "[...] ego [...] semper adhibui praecipuos canes, Platonem scilicet, et Aristotelem". ${ }^{67}$ One understands that the goal of his work was to establish that both 'dogs' had gone always the same way whenever they had reached some fundamental crossroads.

The century ended with some other interesting appearances of the investigative dog. Around 1592 Thomas Nash recounted the episode of the Dog almost verbatim in his poem Summers Last Will, a passage that will re-appear again in S. Rowlands' Greene 's Ghost Haunting (1602). ${ }^{68}$ In 1598 Tycho Brahe published his Astronomiae Instauratae Mechanica. In one of the plates, he added among his various instruments the image of his favourite dog, represented at his feet, as "[...] a symbol not only of his noble race but also of sagacity and fidelity". ${ }^{69}$ A year later, Giovan Battista della Porta seemed to be ready to appreciate the basic suggestion contained in Mazoni's Dedicatio. In his physiological work, he portrayed Plato as having an inquisitive head like that of a hound. ${ }^{70}$ 


\section{5. "The significance of the silence of the $\operatorname{dog}^{171}$}

"Chrysippus [...] considerant les mouvements du chien qui, se rencontrant en un carrefour à trois chemins $[. . .]^{172}$, we do not need to read all of this French version of the adventure of the dog, for it belongs to a very close transliteration either from Sextus or more likely from Plutarch ${ }^{73}$ that Michel de Montaigne inserted in his "Apology for Raymond Sebond" in 1580, that is in time to allow one to conjecture that the Essays may have further spread the story of Chrysippus' dog before it would reappear in Ripa. Needless to say, Montaigne was not a mere compiler. While resuming the full philosophical meaning of the dog who makes inferences, he did not insert it within a purely epistemological context, like Sextus, or an ethnological one, like the medieval Bestiari, nor was he interested in casting light on the underlying logic of the argument, like Chrysippus. As we would expect from him, Montaigne was rather inclined to give to the episode an ethical twist, which had a Plutarchian echo. "La presomption est nostre maladie naturelle et originele. La plus calamiteuse et fraile de toutes les creatures, c'est l'homme, et quant et quant, la plus orgueilleuse" ${ }^{174}$. Observed from this perspective, man has no good reasons to consider himself superior to other animals, who, in many cases, must be recognized to be far better equipped by nature to cope with the environment. The inquisitive dog with his rational capacities should remind men of their limits, and teach them some intellectual modesty. Animals do not seek to build ambitious theories of the universe, but cling to their sensations and do not make mistakes. They are happy to live according to nature, inhabiting a world they do not really care to investigate or to know. In this way, Montaigne suggested, brutes manage better than ourselves to live a peaceful life. Sceptics like Sextus Empiricus, Montaigne, Bayle ${ }^{75}$ and, as we shall see in a moment, Hume, have always been among those who share a favourable disposition towards the possibility of animal rationality. Stoics advocated the insertion of brutes in the continuum of creation, but they also drew a sharp line of contrast between them and man, the only rational being. Sceptics recognise no unity between physical reality and mind. There is no anima mundi, no metaphysical guarantee, no rational principle which may grant a full contact between the knower and the external world. Even the desire for knowledge is bound to remain an unfulfillable conatus. And yet, to this form of dualism corresponds in them a certain ease at conceiving of an intimate affinity between human beings and brutes. If man does not have to distinguish, nor detach himself from the rest of the universe in order to state his superiority, he may more easily recognize some kind of fellowship with the other beings. Animals may even rise to 
the role of models of life. The epistemic fracture, perceived by the sceptics between mind and being, appears to drive them towards a sense of harmony with respect to the rest of the living world.

The answer to Montaigne's 'theriophily' had to wait some decades. At the beginning of the new century, Chrysippus' dog could still enjoy the protection of no less a person than King James I. When the latter visited Cambridge, in March 1614-5, a disputation between John Preston and Matthew Wreb was organized. At the end of the Philosophy Act the question was "whether dogs could make syllogisms". ${ }^{76}$ Preston urged that they could. An enthymeme is what the dog has in mind at the trivium (in fact Preston proposes a bivium: either this way or that way, but not a therefore b). Wreb replied that dogs may be nasutuli but not logici. At this point the King himself intervened in favour of the rationality of the animals. His conclusion was that either Wreb had to think better of his dogs or not so highly of himself. The culture of the time was changing. The rationality of the quadruped had started to require an authoritarian defence. Three decades later, Descartes wrote to the Marquis de Newcastle: "as for what concerns the capacity of understanding and thinking that Montaigne and some others attribute to brutes, I cannot be of the same opinion"77.

Descartes' negative attitude towards animals was motivated by two series of reasonings. In the first place - he maintained somewhat like Philo - there were "two very certain means of recognizing that they [machines looking like men, thus brutes as well] were not real men. The first is that they could never use words, or put together other signs, as we do in order to declare our thoughts to others. [...] Secondly, even though such machines might do some things as well as we do them, or perhaps even better, they would inevitably fail in others, which would reveal they were acting not through understanding but only from the disposition of their organs ${ }^{178}$. By the former argument, Descartes could distinguish between men and animals: the silence of the dog was still very significant. By means of the latter argument, non-biological machines were equally eliminated. A high degree of adaptability to contingent situations became the manifest sign of intelligence, and one that any kind of machine seemed to lack. Three centuries later the same argument can still be used against computers. In the second place, according to Descartes' system the occurrence of some rational activity demanded the presence of a mind-soul, which then had to be considered self-conscious and, being separated from the body, eternal. It followed that brutes could not be endowed with rationality because Descartes was unwilling to accept either of the following two alternatives: brutes possessed an immortal soul - something which 
looked unlikely to him when he thought of the lowest forms of life - or, if their soul was not be immortal after all, then man's too might not be. "Is it not a fearful piece of evidence to grant reason to creatures that have no inherent knowledge of God?" Plutarch had already asked in a similar context. ${ }^{79}$ The debate upon the rationality of animals with Henry More and Pierre Gassendi developed on the basis of this question.

The controversy with More indicates how different the latter's Renaissance perspective was from the Cartesian one. More understood very well why Descartes wanted to deny rationality to brutes, but he could not share the same presuppositions, at least not all of them. Although he considered himself for a long time a supporter of Descartes' method, in An Anthidote against Atheism he spelled out that "Des-Cartes, whose Mechanical wit I can never highly enough admire, might be no Master of Metaphysics to me" ${ }^{180}$. More's position was understandable: his universe was not a mechanical device but a world imbued with spirituality and rational harmony. His God was a great Artist, perhaps an Architect, surely not an Engineer. Thus, he could not understand how the limited framework allowed by Descartes' negative conception of the spiritual life of brutes could account for "illa vulpium canumque astutia et sagacitas". ${ }^{81}$ The question does not lie on "aut sensu spoliare, aut donare immortalitate ${ }^{182}$ but rather on whether we are ready to recognise the universe as the creation of an overpowering Omnipotent, who has left in it distinct and incontestable traces of His logical plan. Indeed, in another context More contended that the rational behaviour of animals - and of dogs when they are hunting for prey - is an explicit sign of the existence of God. If this may ultimately urge the necessity to attribute an immortal soul to brutes as well, where was the problem? "[...] if the $\underline{\text { Souls of Brutes prove immortal }}$ (which the best of Philosophers have not been averse from) the Tragedy is still lesse horrid ${ }^{183}$ than endorsing the view of a mechanical and mindless world.

In his reply, Descartes rejected all of More's suggestions. Animals are at most endowed with an anima corporea, but by no means with anything remotely resembling a mens. Descartes' hostile reaction to the possibility of attributing to brutes some rational capacity was also a reflection of his contempt for both scholastic and Renaissance culture, for occult and confused connections among creatures and creator, mind and body, knower and known. His was a systematic philosophy of order, and the latter was to be obtained by an organization of the continuum into a reconstructed whole of segments and patterns. Cartesian rationalism was therefore bound to be rich in dualisms. In the case under 
examination, the universe had to be arranged as the Stoics did centuries before, by drawing a sharp demarcation between rational beings, that is God and men, and a-rational creatures. When compared to the rational beings, brutes should be considered nothing more than well-constructed machines. As for the "astutia \& sagacitas canum et volpium", or any other phenomenon caused by the need for food or the desire to escape pain and danger, Descartes wrote to More that it was possible "a sola membrorum conformatione profecta explicare". ${ }^{84}$ Animals had at most a successful instinct. Away with these ideas about their intelligent behaviour!

More was not a person to be discouraged by a negative reply, so the correspondence between the two continued for some time, although no real rapprochement of their positions was in view. Their reasonings, one is entitled to suspect, originated from a common assumption: God expresses His greatness in the creation of the universe. More's Renaissance outlook, however, let him interpret such greatness in terms of a flow of spirituality from the source down to the most humble creature. It is interesting to note that in one of his letters he refers to Ficino and his definition of 'anima' as 'vita mundi'. ${ }^{85}$ Descartes' modern mentality made him interpret such greatness in terms of the invention of a perfect machine, which required no further intervention. Would God be greater in constructing a perfect clock or in infusing in all the universe a trace of His spirituality? European culture was leaning with Descartes in favour of the first option.

Gassendi had different reasons from More to disagree deeply with Descartes about the issue of the rationality of animals. He made his point very clear in his Objections against the Meditations. The arguments used by Descartes to prove that animals are mere automatons, created by the Eternal Engineer as incapable of language or any form of reasoning, slave of their impulses and lacking any freedom, had to be dismissed as too extreme. "You may say that animals do not employ rational arguments. But although they do not reason so perfectly or about as many subjects as man, they still reason, and the difference seems to be merely one of degree" ${ }^{186}$. Having stated this slightly sceptical point, Gassendi politely recognized that the context did not allow for a lengthy discussion. But he was too well versed in sceptical literature not to resort to the episode of Chrysippus' dog. ${ }^{87}$ So as soon as he had some more space he exploited the image to advocate his theory that, between the 'intellectus' which belongs to man only, and the 'sensus', the capacity of perceiving the world, there is a natural faculty, a 'phantasia', which is a capacity of apprehending, affirming and negating, and then reasoning upon bare 
information provided by the senses, a sort of natural intellect with which every living being is endowed. Indeed, Gassendi thought man had better learn something from the other living creatures, and trust experience more than mere logic, for "what olfactory sense is logic endowed with that it sniffs out and runs to ground the hidden nature of things?". ${ }^{88}$ The sooner empirical experience will replace scholastic syllogisms the better it will be for the development of human knowledge.

The description of the Cartesian career of Chrysippus' dog would not be complete now, without a further consideration. We do not know whether Descartes ever read Sextus Empiricus. His formulations of the sceptical challenge invite the reader to surmise that there may be a concealed influence, yet no explicit passage or reference to the most important work of ancient scepticism has been uncovered so far. In fact, Diogenes Laertius' Life of Pyrrho may be a far more illuminating source than the Outlines, in order to explain Descartes' knowledge of Pyrrhonism. We have seen that Descartes dedicates a conspicuous part of his work to the question whether animals are capable of reasoning. His writings contain references to several fanciful stories about the issue. Still, to my knowledge he never discussed the adventure of the dog at the trivium, not even in a vaguely implicit manner, ${ }^{89}$ despite the fact that the episode was well known at his time. Just to give one more example, in the same years in which Descartes was exchanging his correspondence with More, Buonaventura Cavalieri could compare the work of the geometricians to that of hunting dogs after prey. ${ }^{90}$ The absence of Chrysippus' rational dog in Descartes' works is therefore an interesting piece of further negative evidence. Descartes' silence upon the episode supports the conjecture that he probably never read the Outlines. If he had, presumably he would have remembered the entertaining episode. 


\section{6. "I am a dog-fancier myself"}

Between the end of the seventeenth and the beginning of the eighteenth centuries the querelle des bêtes changed its character. ${ }^{92}$ Man was still in the centre of attention - in the seventeenth century the main concern is not with animals as such but still with the superiority of mankind, his soul, morality and intelligence, his place in the chain of being etc. - but by means of discussion about brute souls, a lot began to be said about the nature of animals as well. The exaltation of beasts was cemented to the discussion about the value of education and the positive aspects of the life led by the 'noble savage'. Its corollary was generally a form of more or less enlightened conservatism typical of country dwellers, of the type shared by Montaigne as well as by most of the Green Parties of our days. In Descartes, the ethical, theological and epistemological values were predominant with respect to ethnological, biological and zoological issues. The crisis of religious faith, the new discoveries in anthropology, biology and zoology, and finally Darwin, forced Western culture to change its attitude, and pay attention to questions such as hunting, vivisection and cruelty towards animals. In this process, Chrysippus' dog gained his usual share of praise from people like Saunier de Beaumont and the Maquis d'Argens ${ }^{93}$ and in the long run even Darwin himself. ${ }^{94}$ Before them, however, another visitor of La Flèche had opened the path to an anti-Cartesian approach. In his usual, straightforward style David Hume remarked that "[...] no truth appears to me more evident, than that beasts are endow'd with thought and reason as well as men. The arguments are in this case so obvious, that they never escape the most stupid and ignorant" ${ }^{195}$. So much the worst for Monsieur Descartes, one may add.

As far as the question of animal rationality is concerned, Hume's naturalism was closer to Sextus' Pyrrhonism than to the moral approaches of Montaigne and Bayle. A philosophical system purporting to explain human knowledge must be able to interpret by the same token animal intelligence as well. Hume was confident that his theory accomplished both tasks. He was probably right, if one considers that his system had already deprived human knowledge of its most ambitious claims, and reduced reason to "nothing but a wonderful and unintelligible instinct in our souls, which carries us along a certain train of ideas, and endows them with particular qualities, according to their particular situations and relations ${ }^{196}$. At the end of Book I of the Treatise, Hume could easily contend that beasts and men do not really differ in their cognition. All living beings perceive no real connections among objects or events, but they draw their conclusions compelled by experience and custom. The old hound, who 
knows better than the young how to hunt his prey, is a significant example of how close men and beasts are in their experiences. ${ }^{97}$ One may wonder whether Hume had not so much elevated the status of brutes as reduced that of man.

Reasoning by analogy has an important place in Hume's philosophy. By its means the mind can overcome the limits of experience. In general agreement with Porphyrius, the other defender of the dog's 'epistemic rights', Hume maintained that following our impressions, according to which similar effects refer to similar causes, behaviours that look rational are likely to be related to commensurable rational origins. The fact that the defence of animals is based upon such a procedure places Hume in complete contrast with Descartes, who rejects any analogical comparison between man and animals as a thoroughly unjustifiable, epistemological methodology (almost two centuries have elapsed since the analogical speculations of Renaissance philosophers had 'obscured' the path to truth). For Descartes, the occurrence of equivalent behaviours and faculties, or physiological features, may be due to completely different causes, thus related to opposite explanations. ${ }^{98}$ The rationalist was compelled by the extreme nature of his position to rely on the notion of logical possibility, as any other good sceptic would do, while the empiricist, having eliminated the logical force of the concept of causality, was able to rely on less compelling epistemological standards, such as the notion of analogy, the acquisition of knowledge through repeated experience and the association of data. As in antiquity, our dog had an easier life in a context dominated by principles less strictly rationalist.

\section{7. "The Dog, of course, was aware of the change"}

If the command of a language must count as the principal criterion for establishing whether or not a being is intelligent, then Chrysippus' dog has little hopes of passing the examination. We know that this was the case with the Stoics. We have seen Descartes arguing in the same direction. We expect the same attitude in Wittgenstein's philosophy.

Wittgenstein acknowledged that contrary to cats, dogs can be trained to retrieve, ${ }^{100}$ but this is the most he was able to concede to the seemingly rational behaviour of our dog. Within his philosophy, with its fundamental conception of rational life as one based on symbols and interpretations, as well as its stress on the capacity to learn and follow the rules of language-games, it is impossible to concede any real intelligence to the animal. And yet, this is not a completely negative result. Because they cannot be 
sincere, dogs and children cannot lie either. ${ }^{101}$ They still live an existence in which there is no separation between knowledge and reality. They lack the instruments to entertain hopes and fears with respect to the future, ${ }^{102}$ to negate matters of facts, to draw analogies among different events or objects, to simulate certain feelings, ${ }^{103}$ to develop a conversant awareness of themselves. ${ }^{104}$ Animals and children live in a world which has only one dimension, the existing present and the continuous experiencing of it. The difference lies in the fact that human beings soon escape from such a direct acquaintance with the present, thanks to the semiotic medium.

Wittgenstein re-launched the debate upon animal rationality, and later philosophers have followed the path laid down by centuries of tradition. Theological problems have disappeared, man's anthropocentrism has been undermined, and the conceptual tools have been sharpened, but the similarities are evident. After al, the number of intelligent things that can be said about the issue is limited. Thus, Norman Malcolm, ${ }^{105}$ starting from the analysis of Descartes' negative attitude, has defended a position that can be easily related to that of Porphyrius. Discussing the behaviour of his dog, he remarks that we need to distinguish between having thoughts - something which requires a mind and a language - and thinking, believing, fearing and so on, mental attitudes that require only a mind, but not a language. Animals do not entertain propositional contents, but they do have mental attitudes, so they enjoy a certain measure of rationality. On the other hand, Donald Davidson can be listed among the followers of Philo of Alexandria: in his debate with Malcolm he has stressed that to be rational is to have knowledge not only of one's own thoughts, but also of the fact that one holds those thoughts. Rationality is a holistic feature which cannot occur without a language. Since animals are 'a-logical', they cannot be credited with rational thoughts. Contemporary, analytic philosophers like to rely on the discussion of illustrative cases, and sometimes Chrysippus' inquisitive dog has found his natural place in books on logic. ${ }^{106}$ At other times, however, he has been replaced by the unpleasant figure of "a superdog from another planet" capable of intelligent inferences. ${ }^{107}$ What a shame.

\section{Conclusion}

The traces of Chrysippus' dog have left a path in the history of thought. By following them we have now reached the present age, when I guess a final, general reflection won't be out of order. 
Each epoch has created its own typology of the inquisitive mind. Odysseus can be considered the Platonic hero. His travelling towards new knowledge is a coming back home, and even the story of his deeds is partially recounted from the end. Faust is the Baconian hero, who escapes from his room for a voyage into the world which will take him 'plus ultra', beyond Hercules' pillars. Sherlock Holmes represents the modern, Peircean hero, immersed within his culture and history, whose abductive capacities are exercised on social affairs rather than on the natural world. As in Ripa's iconography of 'Investigazione', our intelligent dog has accompanied all of these characters in their adventures. He has faithfully waited and recognized Odysseus, tempted Faust ${ }^{108}$, and helped Holmes. Literature, as well as philosophy and the visual arts, have all acknowledged their debt to the figure of the hunting animal, but has our culture shown some self-awareness with respect to such an intriguing phenomenon? I seem to catch a very pleasant and not incidental coherence in the fact that in our century as speculative a writer as Kafka, so susceptible to the relationship between man and animals, has written a story entitled "Forschungen eines Hundes", ${ }^{109}$ in which a philosophical and investigative dog recounts his adventures in search of the true nature of his 'dogness' along the line of the Socratic model. I find it reassuring to know that, in the long run, thought has a healthy tendency to become transparent to itself. ${ }^{110}$ 


\section{Notes}

1) G. Frege, "On Sense and Meaning" in Translations from the Philosophical Writings, ed. by Peter Geach and Max Black (Oxford: Blackwell, 1952) p. 59.

$\left.{ }^{2}\right)$ C. Doyle, "The Adventure of the Creeping Man", in The Penguin Complete Adventures of Sherlock Holmes (London: Penguin, 1988) p. 1071. All following references are to this edition.

$\left.{ }^{3}\right)$ C. Doyle, "The Return of Sherlock Holmes: The Adventure of the Missing Three-Quarter", p. 633.

$\left.{ }^{4}\right)$ C. Doyle, "The Case Book of Sherlock Holmes: The Adventure of Shoscombe Old Place", p. 1108. The original text reads "her" instead of "his".

5) See Roberto Barbolini, Il Detective Sublime, Sul Romanzo Poliziesco (RomaNapoli: Theoria, 1988).

9) David Hume, A Treatise on Human Nature, ed. by P. H. Nidditch (Oxford: Clarendon Press, 1978) Book II, Part III, Sect. X, "Of Curiosity, or the Love of Truth".

7) On Ripa's life see now Chiara Stefani, "Cesare Ripa, New Biographical Evidence", Journal of the Warburg and Courtauld Institutes, 53 (1990) pp. 307-312.

$\left.{ }^{8}\right)$ Ripa's Iconologia (Siena, 1613) pp. 387 f., my translation of the following passage: "Donna con l'ali alla testa [...] mostrando [...] col dito indice della sinistra, un Cane, il quale stia con la testa bassa per terra in atto di cercare la fiera. L'ale [...] significano l'elevazione dell'intelletto, perchè alzandosi egli [...] viene in cognizione delle cose alte, e celesti. [...] Del significato del Cane, Sesto Pirhonese Filosofo nel primo lib. cap. 14 dice, che il cane [...] denota investigatione, percioche quando seguita una fiera, ed arrivato ad un luogo, dove sono tre strade, e non havendo veduto per qual via sia andata; esso 
odorata, ch'abbia la prima strada, odora la seconda, e se in nessuna di esse sente, che sia andata, non odora la terza, ma risoluto corre argomentando, che necessariamente sia andata per essa." The quotation comes from from the fourth edition. Mason Tung has recently provided a study of sixteen editions and several reprints of Ripa's Iconologia, with a concordance of the various entries, see his Two Concordances to Ripa's Iconologia (New York: AMS Press, 1993). Tung has shown that most of the illustrations appeared in the translations (especially French) of the Italian editions. His suggestion is further supported by a little volume, entitled Le miroir des princes, représentés en figures de taille douce des recherches du chevallier C. Ripa [in his Iconologia] (Paris, 1604). The copy I have been able to check in the Bodleian library consists of fifteen folios only, the first of which bears a dedication by "Michel van Lochom, Graveur et Imprimeur du Roy pour les tailles douces" to "Monsieur Morin Escuier [...]", while the others present the following personifications: Noblesse, Magnificence, Maiesté, Religion, Iustice, Pitié, Force, Prudence, Science, Prévoyance, Mars, Paix, Tranquillité, Chasse. There is not one line of text. According to Yassu Okayama, The Ripa Index $\underline{\text { Personifications and Their Attributes in Five Editions of the Iconologia }}$ (Doornspijk: Davaco, 1992), the entry 'Investigazione' appeared with an illustration from the 1624 edition onwards. A late engraving is in Iconology, or a Collection of Emblematical Figures Chiefly Composed from the Iconology of Cesare Ripa, collected and arranged by George Richardson (London: G. Scott, 1779), in which the reference to Sextus Empiricus is missing, see vol. II, p. 26, fig. 236.

9) Sextus Empiricus, Outlines of Pyrrhonism, I, 69-70, Greek ed. with Eng. tr. by R. G. Bury (Cambridge Mass.: Harvard U.P., 1933) p. 43, my alterations. Another, more synthetic reference to Chrysippus' dog is in Sextus Empiricus, Against the Logicians II, 271-5 (Adv. Math. VIII), Greek ed. with Eng. tr. by R. 
G. Bury, (Cambridge Mass.: Harvard U.P. 1935) p. 379. A version of the syllogism is in the Outlines II, 150, on which see Otto Apelt "Zu Sextus Empiricus" Rheinisches Museum 39 (1884) pp. 27-33. For a translation of the relevant passages, see Julia Annas and Jonathan Barnes, The Modes of Scepticism: Ancient Texts and Modern Interpretations (Cambridge: Cambridge U. P., 1985), pp. 31-53 on "Humans and other Animals" and now Outlines of Scepticism, Eng. tr. by Julia Annas and Jonathan Barnes (Cambridge: Cambridge U. P., 1994), in which the two translators devote some space to Chrysippus' dog.

${ }^{10}$ ) I have analysed the rediscovery of Sextus Empiricus in the Renaissance in "Sextus Empiricus in the Renaissance", Journal of the History of Ideas, 56.1 (1995), pp. 63-85. On the first edition of the Latin edition of the Outlines and the "cognizione delle cose alte", as Ripa expresses himself, see my "The Grafted Branches of the Sceptical Tree: 'Noli altum sapere' and Henri Estienne's Latin Edition of Sexti Empirici Pyrrhoniarum Hypotyposeon libri III", Nouvelles de la République des Lettres (11) 1992, pp. 127-166. I hope to deal with the manuscript and editorial tradition of Sextus' works exhaustively in the article "Sextus Empiricus" for the Catalogus Translationum et Commentariorum.

${ }^{11)}$ The Iconografia contains many dogs, portrayed in various different postures, so historians have never felt the necessity of a close analysis of the rational dog at the crossroads. Neither Erna Mandowsky, Untersuchungen zur Iconologie des Cesare Ripa (Dissertation, Hamburg 1934; It. tr. Firenze, 1939) nor Gerlind Werner in her Ripa's "Iconologia": Quellen, Methode, Ziele (Utrecht: Haentjens, Dekker \& Gumbert, 1977) concentrate on the two entries 'Investigazione' and 'Dubbio'. For an analysis of other occurrences of the figure of the dog in Ripa see F. F. De Daugnon Il Cane nella storia e nel mondo simbolico (Crema 1907, 2nd ed.) pp. 30-33, who refers to the Iconologia edited 
by the abate Orlandi (1765). He notices the presence of a dog in 'Amicizia', 'Botanica', 'Confessione Sagramentale', 'Fedeltà', 'Gioventù', 'Memoria', 'Tregua', 'Lussuria', 'Miseria', but not in 'Investigazione'.

${ }^{12}$ ) Sextus Empiricus, Outlines, I.40

${ }^{13}$ ) Both quotations are from Outlines I.62-63.

${ }^{14}$ ) Ripa, Iconologia, pp. 65 f. (Rome 1593), my translation of the following passage: "Huomo ignudo, tutto pensoso, incontratosi in due, ovvero tre strade, mostri esser confuso, per non saper risolvere qual di dette vie debbia pigliare. Et questo è dubbio con speranza di bene, come l'altro con timore di cattivo successo, \& si fa ignudo, per essere irresoluto". 'Dubbio' is not illustrated in any of the five editions examined by Okayama, The Ripa Index. For an image of the entry one can consult Iconologu, the English translation quoted above, vol. I, p. 85, fig. 157

${ }^{15}$ ) See Wolfgang Harms, Homo Viator in Bivio, Studien zur Bildlichkeit des Wegens (München: W. Fink Verlag, 1970). As one would expect, the text contains no reference to Chrysippus' dog or to the episode narrated by Sextus Empiricus.

$\left.{ }^{16}\right)$ On the iconography of crossroads see Martin Ruhvel The Crossroads in Folklore and Myth (New York: Peter Lang, 1989), which contains no reference to Sextus.

${ }^{17}$ ) See E. Panofsky, Hercules am Scheidewege, Studien der Bibliothek Warburg XVIII (Leipzig: 1930) and E. Tietze-Conrat "Notes on Hercules at the Crossroads", The Journal of the Warburg and Courtauld Institutes 1951 (14) pp. 305-309.

${ }^{18}$ ) Picinelli is the only other reference given by Iconclass relevant to our subject, cf. H. van de Waal, Iconclass, an Iconographic Classification System, comp. and ed. by L. D. Coupriee with E. Tholen and G. Vellekoop (Amsterdam, Oxford, New York: North-Holland Publishing Comp., 1985), under 'doubt'. For 
Picinelli see Mundus Symbolicus, 1687, re-edited with an introduction and a bibliography by Dietrich Donat (Hildesheim-New York: Georg Olms Verlag, 1979).

${ }^{19}$ ) Picinelli, Mundus, lib. IX, cap. IV, n. 71 (tom. I, p. 549 col. a).

${ }^{20}$ ) Picinelli, Mundus, lib. XIX, cap. XIV n. 62 (tom. II, p. 146b). For the iconology of 'Investigation' and the figure of the hunting dog cf. vol. I, p. $357 \mathrm{a} / \mathrm{b}$, with a reference to Cyrillus Alexandrinus' comparison between the dog and the wise man.

$\left.{ }^{21}\right)$ C. Doyle, "The Adventures of Sherlock Holmes: The Adventure of Copper Beeches", p. 331.

$\left.{ }^{22}\right)$

Theognis, The Elegiac Poems, I.909-914, Greek ed. with Eng. tr. by J. M. Edmonds (Cambridge Mass.: Harvard U.P., 1982) vol. I, pp. 336 f., my modified translation.

${ }^{23}$ ) But apparently not only of the sixth century. I'm told that in modern Greek is a common locution to express the state of doubt.

${ }^{24)}$ Plato Laws VII, 799c-d, Greek ed. with Eng. tr. by R. G. Bury (Cambridge Mass.: Harvard U.P., 1952) vol. IX, pp. 39-41.

${ }^{25}$ ) Not only because of the classic process of diairesis, but also because of the context.

${ }^{26)}$ M. T. Cicero, De natura deorum and Academica, Eng. tr. by H. Rackham (London: Heinemann, 1972) 2.158. Cicero speaks about the various forms of syllogism, but not about the intelligent dog, in $\underline{\text { Topica }} 57$ and ff., see Scripta quae manserunt omnia, recognovit C. F. Müller (Bibliotheca Scriptorum Graecorum Teubneriana, Lipsiae, 1893) Pars I, vol. 2, p. 438 and ff.

${ }^{27}$ ) See Nicholas J. Zaganiaris "Le Chien dans la mythologie et la littérature gréco-latines", Platon 32-3 (1981) pp. 52-85, esp. pp. 71 f.; Jost Perfahl 
$\underline{\text { Wiedersehen mit Argos und andere Nachrichten über Hunde in der Antike }}$ (Mainz am Rhein: Verlag Philipp von Zabern, 1983), in which we find Aelianus' story of Chrysippus' dog (pp. 29-30); Carla Mainoldi, L'Image du loup et du chien dans la Grèce ancienne, d'Homère à Platon (Paris: ed. Ophrys, 1984) and Beryl Rowland, Animals with Human Faces (Knoxville: The University of Tennessee Press, 1973, rep. London: Allen \& Unwin, 1974) pp. 58-66, who provides useful information on various ideas related to the theme of the dog. None of these texts contains, or refers to, any illustration of a dog in a trivium. For a representation of the philosophical dog, see Frans II Francken's Allegory of Good Fortune (1627) and Giovanni da Bologna's Medici Allegory (ca. 1560), both described in Patrik Reuterswaer "The Dog in the Humanist's Study" Konsthistorisk Tidskrift, 50 (1981) pp. 62-63, fig. 16 and 17.

${ }^{28}$ ) Karl A. Neuhausen has studied the figure of the 'philosophical dog' in Plato in his "Platons philosophischen Hund bei Sextus Empiricus" Rheinisches Museum 118 (1975) pp. 240-64. According to him, Outlines I, 62-78 is directly connected to Plato's Rep. II 374e6-376c5. Neuhausen quotes and discusses Olympiodorus' interpretation on p. 260.

${ }^{29}$ ) Plato speaks of the philosophical dog in Republic II, 375a-376c, Greek ed. with Eng. tr. by P. Shorey (Cambridge Mass.: Harvard U.P., 1930) vol. I, p. 173. The dog changes his behaviour towards man depending on whether he knows him or not, thus he acts on the basis of knowledge and "shows a true love of wisdom". On the topic see T. A. Sinclair "Plato's Philosophic Dog" The Classical Review 57 (1948) pp. 61-62: "nature shows that a dog is philomates, and if a dog, then according to the phusis theory, also a man; and if philomates then also philosophos. There is a particular pleasure in hoisting your opponent with his own petard". I own to Prof. Dorothea Frede a suggestion concerning C. J. Classen, Untersuchungen zu Platons Jagdbildern (Berlin, 1960), a text which I hope to study in the future. 
${ }^{30}$ ) For the fragments concerning Chrysippus' fifth syllogism see now Karlheinz Hülser, Die Fragmente zur Dialektik der Stoiker (Stuttgart: FrommannHolzboog, 1988) Band 4, pp. 1596-1605, frag. 1154-1159, original texts with German translation. Hülser's improves on von Arnim's collection.

$\left.{ }^{31}\right)$ C. Doyle, "Memoirs of Sherlock Holmes: The Reigate Puzzle", p. 404

${ }^{32}$ ) On Stoics' logic, cf. Benson Mates, Stoic Logic (Berkeley and Los Angeles: University of California Press, 19531-19612), who discusses the example of the dog on p. 80; Michael Frede, Die Stoische Logik, Abhandlungen der Akademie der Wissenschaften in Göttingen, Philologish-historische Klasse, Dritte Folge, Nr. 88 (Göttingen 1974) pp. 155-7 on the dog; Mario Mignucci, Il Significato della Logica Stoica (Bologna: Patron, 1965); J. B. Gould, The Philosophy of Chrysippus (Brill: Leiden, 1970) esp. chap. IV; Mariano Baldassarri, Introduzione alla Logica Stoica (Como: 1984), and finally W. Kneale and M. Kneale The Development of Logic (Oxford: Clarendon Press, 1962) esp. p. 167.

${ }^{33}$ ) Sherlock Holmes to Watson in C. Doyle, "The Adventure of the Beryl Coronet", p. 315.

${ }^{34}$ ) The more general issue of animal rationality is now discussed by Richard Sorabji in his Animal Minds and Human Morals - The Origins of the Western Debate (London: Duckworth, 1993). See also S. O. Dickermann "Some Stock Illustrations of Animal Intelligence in Greek Psychology" Transations and Proceedings of the American Philological Association 42 (1911), pp. 123-130.

${ }^{35}$ ) See Cléomède, Théorie E'lémentaire (De Motu circulari corporum caelestium) texte présenté, traduit et commenté par Richard Goulet (Paris: Vrin, 1980) pp. 11-115 and notes 158 .

${ }^{36}$ ) Philonis Alexandrini De Animalibus adversus Alexandrum, the Armenian text with an introduction, translation and commentary by Abraham Terian (Ann Arbor: Scholar Press, 1981, French edition, shortened, Paris: éditions du 
Cerf, 1988), see par. 45 (p. 86-87) for Alexander's position and par. 84 (p. 102 103) for Philo's.

${ }^{37}$ ) The Alexander in question could either be Philo's younger brother or his (Alexander's) son, Tiberius Julius Alexander; the issue is discussed by Georg Tappe' De Philonis Libro [...] (Göttingen, 1912), see also Erwin R. Goodenough, An Introduction to Philo Judaeus, 2nd ed. (Oxford: Blackwell, 1962), p. 50, note 30.

$\left.{ }^{38}\right)$ D. J. O'Connor The Correspondence Theory of Truth (London: Hutchinson, 1975) chap. 5, quotation from p. 31.

${ }^{39}$ ) For a quotation and a more detailed discussion of Chrysippus position with respect to Porphyrius see the latter's De l'Abstinence, texte établi et traduit per J. Bouffartigue et M. Patillon (Paris: Société d'édition "les belles lettres", 1979) vol. II, p. 152, note n. 2.

${ }^{40}$ ) Richard Sorabji provides a different explanation (cf. Animal Minds, p. 21-26). He argues that by sketching the image of the dog at the trivium Chrysippus was perhaps conceding to the dog the capacity of behaving on the basis of his perceptual appearances. I find difficult to accept this possible explanation.

$\left.{ }^{41}\right)$ A. Dyroff "Zur Stoischen Tierpsychologie", Blätter für das bayerische Gymnasialschulwesen 33 (1897) pp. 399-404, and 34 (1898) pp. 416-430.

${ }^{42}$ ) Plutarch, Moralia, De Solertia Animalium, Greek ed. with English tr. by Harold Cherniss and William C. Helmbold, with the title "Whether Land or Sea Animals are Cleverer" (Cambridge Mass.: Harvard U.P., 1957) vol. XII, pp. 311 486, quotation from p. 377 (969.a-b). See also the important episode of the fox, who adopts a similar 'reasoning' on p. 377 (986.f).

${ }^{43}$ ) Homelia n. IX.4 (I 84d) "On terrestrial animals", in Basile de Césarée, Homélies sur l'Hexaéméron, text Grec, introd. et trad. de Stanislas Giet (Paris: Les éditions du Cerf: 1949) p. 501; and Patrik Reuterswaer, art. cit. 
$\left.{ }^{44}\right)$ See Enzo Lucchesi L'usage de Philon dans l'oeuvre exégétique de saint Ambroise - une "Quellenforschung" relative aux commentaires d'Ambroise sur la Genèse (Leiden: Brill, 1977).

${ }^{45}$ Sancti Ambrosi Hexaemeron Libri Sex De Opere Sexti Diei, in Opera Omnia, Tomi Primis Pars Prior ed. by J. P. Migne in Pat. Cur. Comp. s. L. (Paris: 1845) vol. 141, col. 250-251. According to Ambrose "Nobody doubts that the dog is animated by a form of rationality". It is interesting to note that for his knowledge of the episode Ambrose is heavily relying upon Plutarch. He has the same comparison between the intelligent dog and "the philosophers, who, seated in front of geometrical figures, draw lines in the sand and, confronted with three propositions, have to discard two in order to discover the truth of the one that remains" (Nonne totos dies conferunt philosophi propositiones sibi in pulvere dividentes, qui radio sibi describunt singulas, et ex tribus cum unam earum veram esse necesse sit, duas primo interficiunt tamquam mendacio congruentes, et sic in ea quae relicta est, vim veritatis inhaerere defiunt?"). The figure of the dog has acquired a slightly anti-intellectualist meaning.

${ }^{40}$ On the Characteristics of Animals VI.59, Greek ed. with Eng. tr. by A. F. Scholfield (Cambridge Mass.: Harvard U.P., 1959) vol. II, pp. 82-83.

$\left.{ }^{47}\right)$ See for example Plato, Theaetetus, 206d and ff. and Aristotle, De

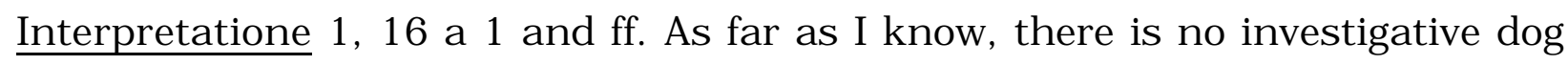
in Aristotle himself, but a hint at the episode of the trivium can be found in the summary of the historia animalium by Aristophanes of Byzantium, cf. Aristophanis historiae animalium epitome, in Commentaria in Aristotelem Graeca suppl. 1.1 (Berlin: Reimer, 1885) p. 93. On the problem of levels of linguistic activity in antiquity see R. Sorabji "Myths about Non-propositional Thought" in M. Schofield and M. Craven Nussbaum (eds.) Language and Logos (Cambridge: Cambridge U.P., 1982), pp. 295-314. 
${ }^{48}$ ) Porphyrius, De Abstinentia, lib. III, see esp. par. 2, p. 153 for the episode of Chrysippus' dog. For Porphyrius' influence on Voltaire see Renato Galliani "Voltaire, Porphyre et les animaux" in Studies on Voltaire and the Eighteenth Century (Oxford: Voltaire Foundation, 1981) pp. 125-138, for his influence on Basilius see E. Gilson, History of Christian philosophy in the Middle Ages (London: Sheed and Ward, 1955) pp. 581 f..

${ }^{49}$ ) Sextus Empiricus, Outlines, I, 65 and ff..

${ }^{50}$ ) According to M. Patillon (see ed. of De l'Abstinence cited above), Carneades could be a common source for both Porphyrius and Philo.

$\left.{ }^{51}\right)$ Porphyrius, De Abstinentia, p. 153, Sextus Empiricus, Against the Logicians, II, 287.

$\left.{ }^{52}\right)$ C. Doyle, "The Adventure of Shoscombe Old Place", p. 1109.

${ }^{53}$ ) On the problem of animal rationality in the Middle Age see Tullio Gregory, "L'Uomo di fronte al mondo animale nell'alto medioevo", in Mundana Sapienza, Forme di Conoscenza nella Cultura Medievale (Roma: Edizioni di Storia e Letteratura, 1992).

${ }^{54}$ ) When I gave a paper on the fortune of Chrysippus' dog at the Warburg Istitute, Dr Barnette kindly informed me that Hugh of Fouilloy - who wrote $\underline{\mathrm{De}}$ $\underline{\text { Avibus - and not Hugh of St. Victor, may be the author of De Bestis et Aliis }}$ $\underline{\text { Rebus, }}$ cap. XI "De cane, et ejus natura", which is published under the latter's name in Opera Omnia ed. by J. P. Migne in Pat. Cur. Comp. s. L. (Paris: 1879) vol. 177 , col. $86-87$.

${ }^{55}$ ) Cf. The Book of Beasts, being a translation from a Latin Bestiary of the twelfth century made and edited by $\mathrm{T}$. H. White with a new preface by Francois Gallix (Gloucester: Sutton, 1984), pp. 61-68. The story of Chrysipus' dog is on p. 64: "by rejecting error the Dog finds the truth" following the scent, as if enunciating a syllogism.

${ }^{56}$ ) Gilson, History of Christian philosophy in the Middle Ages, p. 150-153. 
${ }^{57}$ ) See Ioannis Saresberiensis, Polycraticus, Lib. VII, esp. Cap. I, in Opera Omnia ed. by J. P. Migne in Pat. Cur. Comp. s. L. (Paris: 1900) vol. 199, col. $635 \mathrm{ff}$.

${ }^{58}$ ) Ibidem, col. 639.

${ }^{59}$ ) According to the critical note in the Oxford edition of Ioannis Saresberiensis Episcopi Carnotensis Polycratici [...] Libri VIII, recognovit [...] Clemens C.I. Webb, (Oxonii: e Typographeo Clarendoniano, 1909) tom. II, p. 96 (Lib. VII, 639b.25) third note not numbered, John was influenced by Hugh of St Victor, but as I remarked above the latter may not be the author of De Bestis.

${ }^{60}$ ) "[...] the dog, chasing the stag, reached a trivium [my stress], and having smelled the first and the second path, missing any information, run with all certainty in the third direction, without further investigation, as if he had used (quasi utens) a syllogism [...]. From which we can infer that brute have a capacity to choose (electio brutis animalibus conveniat)". Thomas Aquinas, Summa Theologica, Prima Secundae. Quaest. XIII. Art. II.3 ("Utrium electio conveniat brutis animalibus"). Note that, although St Thomas does mention the fact that the dog is mastering some form of syllogistic inference, he does not stop to say which.

${ }^{61}$ ) See Sorabji, Animal Minds, p. 12-20 for a presentation of Aristotle's position and passages in his works where the rationality of animals is discussed, and Hist. Anim. VIII, 1, 558 a 20 and ff., VIII(IX) 1608 a 17, 610 b 22 and 612 a 1 and ff. on the dog, in History of Animals, Greek ed. with Eng. tr. by D. M. Balme (Cambridge Mass.: Harvard U.P., 1991). As Sorabji remarks, these books may be authentic.

$\left.{ }^{62}\right)$ Patrik Reuterswaer writes that "In allegories of logic and thought the dog had come in handy for its intuition and perseverance. The hound of Theory pursuing the hare of Practice, or the hound of Truth and the fox (wolf) of Falsity on the track of the hare Problem, were familiar allegories, which 
proceed from the dog's sagacity and perseverance. Perhaps the first to emphasize this aspect was Basil the Great, bishop of Caesarea in the 4th century, who in his Homilies on Hexaemeron comments on the reasoning of the dog in the following way [...] [here the story of Chrysippus' dog is reported]", art. cit., p. 56.

${ }^{63}$ ) On the figure of the dog in the representation of Melancholy see the classic book by R. Klibansky, E. Panofsky and F. Saxl, Saturn and Melancholy (Nendeln, Lichtenstein: Kraus Reprint, 1979, orig. ed. 1964).

${ }^{64}$ ) See Prologue, 45, the reference is to Plato, Rep. 376b. On the topic, cf. J. Bichon "Sagesse humaine ou sagesse canine?" Études Rabelaisiennes 1969, (8), pp. 85-90.

${ }^{65}$ ) On the equation 'hunger [of the digestive apparatus] : food = curiosity [of the intellect] : knowledge' and its anti-sceptical uses see my "Cupiditas Veri Videndi": Pierre De Villemandy's dogmatic vs. Cicero's sceptical Interpretation of "Man's Desire to Know", forthcoming in the British Journal for the History of Philosophy.

${ }^{60}$ ) See Carlo Ginzburg "Spie. Radici di un paradigma indiziario" in La Crisi $\underline{\text { della Ragione, ed. by Aldo Gargani (Torino: Einaudi, 1979) and now in Il Segno }}$ dei Tre, Holmes, Dupin, Peirce, ed. by Umberto Eco and Thomas A. Sebeok (Milano: Bompiani, 1983) pp. 95-136, Eng. tr. in The Sign of three: Dupin, Holmes, Peirce (Bloomington: Indiana University Press, 1983). Some of the essays discuss the nature of Holmes' rational procedure. Apparently, Doyle was rather generic and called it deduction, whereas it should be identified more precisely with what Peirce called abduction. The identification is certainly correct, but the previous complaint is unjustified, since in a passage contained in "The Adventure of the Solitary Cyclist" (an episode of The Return of Sherlock Holmes, p. 534) Holmes shouts to Watson: "It's abduction, Watson, abduction!". 
${ }^{67}$ In Universam Platonis et Aristotelis Philosophiam Preludia, Dedicatio, ff. Ia/b, not originally numbered.

${ }^{68}$ ) See The Works of Thomas Nashe, ed. from the original texts by R. B. McKerrow and rep. from the orig. ed. with cor. and sup. notes by F. P. Wilson, in 5 vols. (Oxford: Blackwell, 1966), vol. 4, pp. 428-431 (see the interesting comparison of passages from Sextus, Nash and Rowlands). I own the discovery of this occurrence of Chrysippus' dog in Nash to Rowland Hall.

${ }^{69}$ Tycho Brahe's Description of his Instruments and Scientific Work as given in Astronomiae Instauratae Mechanica (Wandersburgi 1598) tr. and ed. by H. Raeder, E. Strömgren and B. Strömgren (Copenhagen, 1946) p. 31. The Mechanica has been reprinted in facsimile (Bruxelles: Culture and Civilization, 1969).

${ }^{70}$ ) Della Fisionomia dell'Uomo, a cura di Mario Cicognani (Parma: Guanda, 1988, Latin orig. ed. in six libri 1599, tr. It. 1610) pp. 116 f. and 132 f..

$\left.{ }^{71}\right)$ C. Doyle, "Memoirs of Sherlock Holmes: Silver Blaze", p. 349.

${ }^{72}$ ) Michel Eyquem de Montaigne, "Apologie de Raimond Sebond", chap. XII of Les Essays, French ed. by Maurice Rat (Paris: Garnier, 1941) vol. II, pp. 145 f.. For an English translation see now An Apology for Raymond Sebond, translated and edited with an introduction and notes by M. A. Screech (London: Penguin, 1987), and The Essays, translated and edited with an introduction and notes by M. A. Screech (London: Allen Lane, 1991).

${ }^{73}$ ) Plutarch is more likely as a source because of the episode of the fox, which occurs in Montaigne and Plutarch, but not in Sextus Empiricus.

${ }^{74}$ Ibidem, p. 132.

${ }^{75}$ ) Bayle is not favourable to a complete equality between animals and men, but he uses animals in order to undermine human arrogance, see Pierre Bayle Dictionaire historique et critique, ed., rev., cor., et augm. (Amsterdam: P. Brunel, 1740) entries 'Pereira' and 'Rorarius', now in Choix d'articles tirés du 
Dictionnaire historique et critique avec une introduction par Elisabeth Labrousse (Hildesheim, New York: G. Olms 1982; the entry 'Chrysippus' in vol. I of this edition lacks the text from p. 305 to p. 320 included) and partially tr. in Eng. in Historical and Critical Dictionary, ed. by A. Jacob (Dordrecht: Nijhoff, 1987). On the differences between More's and Descartes' conception of the soul see pp. 1xviii-lxxviii.

${ }^{76}$ ) John W. B. Mayor "King James I. On the Reasoning Faculty in Dogs" The Classical Review 12 (1898) pp. 93-96.

${ }^{77}$ ) Third letter to the Marquis de Newcastle, 23 November 1646, in Charles Adam and Paul Tannery Oeuvres de Descartes (henceforth AT, Paris: Vrin, 1972) vol. IV, letter n. CDLX, pp. 568-577, quotation from p. 573. This is the most relevant to our topic of the three letters written by Descartes to William Cavendish. The other two concern mainly medical and physiological issues, see AT (1972) vol. IV, letter n. CCCLXXII, April 1645 [?], pp. 188-192 and letter n. CDX, October 1645, pp. 325-330.

${ }^{78}$ ) Discours de la Méthode, AT (1965) vol. VI, p. 56, Eng. tr. in The Philosophical Writings of Descartes, 2 vols. ed. by J. Cottingham, R. Stoothoff and D. Murdoch (Cambridge: Cambridge U.P., 1985) vol. I, p. 140.

${ }^{79}$ ) Plutarch, Moralia, De Solertia Animalium, p. 531 (992.e).

${ }^{80}$ ) Henry More, An Anthidote against Atheism [...], London 1655, second edition corrected, enlarged and with an Appendix, p. xvi (not originally numbered).

${ }^{81}$ ) More's letter to Descartes, AT vol. V, letter DXXXI, p. 244. See also letter DXLIV, AT vol. V, p. 311.

${ }^{82}$ Ibidem, p. 245.

${ }^{83}$ ) Henry More An Anthidote against Atheism, Appendix: p. 370, italics in the original.

${ }^{84}$ ) Descartes' letter to More, AT vol. V, letter DXXXVII, p. 276. 
${ }^{85}$ ) Descartes had denied that humble animals could have a soul (letter DXXXVII, AT vol. V, p. 277) and More replied that maybe he was right, unless one might trust Ficino when he presented his notion of anima mundi (letter $\mathrm{n}$. DXLIV, AT vol. V, p. 310).

$\left.{ }^{80}\right)$ Pierre Gassendi, Objectiones Quintae, In Meditationem II, sections 7 and 8, AT (1964) vol. VII, pp. 268-274, Eng. tr. in The Philosophical Writings of Descartes, vol. II, p. 189. Descartes does not really answer Gassendi's objection, see his Quintae Responsiones, AT (1964) vol. VII, p. 359, The Philosophical Writings of Descartes, vol. II, p. 247-8.

${ }^{87}$ ) Pierre Gassendi Syntagmatis Philosophici Pars Secunda seu Physica, Sectio III, Liber octavus, Caput IV-V and Liber IX. The episode of Chrysippus' dog, as described by Sextus Empiricus, occurs on p. 414b, but see also p. 410b, a passage that for its reference to the rational behaviour of the fox, already mentioned above, is probably connected to Gassendi's knowledge of Plutarch or of Montaigne. The work has been reprinted in Opera Omnia, FaksimileNeudruck der Ausgabe von Lyon 1658 in 6 Bänden mit einen Einleitung von Tullio Gregory (Stuttgart-Bad Cannstatt: Frommann, 1964) Band 2. Unfortunately, the mentioned texts have not been included in the English translation of The Selected Works of Pierre Gassendi, ed. and tr. by Craig B. Brush, (New York: Johnson Rep. Corp., 1972).

${ }^{88}$ The Selected Works of Pierre Gassendi, p. 63.

${ }^{80}$ ) Descartes speaks of a dog in a Letter to Mersenne, but only in so far as the physiology of the animal is concerned, see AT (1971) vol. III, p. 139-141 and also La Description du Corps Humain, AT (1967) vol XI, p. 243.

${ }^{90}$ Exercitationes geometricae sex (Bologna, 1647) p. 195.

${ }^{91)}$ C. Doyle, "The Adventure of Shoscombe Old Place", p. 1107.

$\left.{ }^{92}\right)$ See George Boas, The Happy Beast in French Thought of the Seventeenth Century (Baltimore: The John Hopkins Press, 1933). I would disagree with 
Boas when he suggests (p. 7) that Sextus Empiricus' presentation of the episode is the source for Montaigne. I think that, because of the episode of the fox, it is much more likely that the latter had in mind Plutarch.

${ }^{93}$ ) H. Hastings, Man and Beast in French Thought of the Eighteenth Century (Baltimore: The John Hopkins Press, 1936) pp. 80-83. The Maquis d'Argens wrote that: "this behaviour of the $\operatorname{dog}$ is an evident proof that his mind is capable of the three operations of logic, and I do not see why a Shock Dog and a Mastiff may not carry his reasoning as far as a Regent of Philosophy in the College of the Four Nations", cited by Hastings in Man and Beast, p. 83, note 1. See also Flourens, De l'instinct et de l'intelligence des animaux (Paris: Garnier, 1841).

${ }^{94}$ ) Charles Darwin, The Descent of Man and Selection in Relation to Sex, 2nd ed. rev. et aug. (New York, London: D. Appleton \& Co. 1930, or. ed. 1871). Darwin negates any "fundamental difference between man and higher mammals" (p. 66). A dog may not have propositional knowledge, but his behaviour is comparable to that of a savage: it is the result of a rational and effective procedure, cf. pp. $76 \mathrm{f}$..

${ }^{95}$ ) D. Hume, A Treatise on Human Nature, Book I, Part III, Sect. XVI, pp. 176179, "Of the Reason of Animals", quotation from p. 176.

$\left.{ }^{9}\right)$ Hume, Treatise, p. 179.

${ }^{97}$ ) Many examples of the intelligent behaviour of the dog occur in the Treatise, but - as one would expect from the more popular nature of the text - the reference closest to the episode of Chrysippus' dog appears in the corresponding section of the Enquiries Concerning the Human Understanding and Concerning the Principles of Morals, ed. by L. A. Selby-Bigge (Oxford: Oxford U.P., 1962) Section IX.

${ }^{98}$ ) See letter DXXXVII of Descartes to More, cited above.

${ }^{99}$ ) C. Doyle, "The Adventure of the Creeping Man", p. 1083. 
${ }^{100}$ The Blue and Brown Books, 2nd ed. (Blackwell: Oxford, 1969) p. 90.

${ }^{101}$ Philosophical Investigations, ed. and tr. by G. E. M. Anscombe, 3rd ed. (Blackwell: Oxford) p. 229e.

${ }^{102}$ ) Ibidem, n. 650.

${ }^{103)}$ Ibidem, nn. 249-250.

${ }^{104}$ ) Ibidem, n. 357.

$\left.{ }^{105}\right)$ Cf. his "Thoughtless Brutes", Proceedings and Addresses of the American Philosophical Association, 46 (1973) pp. 5-20.

${ }^{106}$ ) See Alan Ross Anderson and Nuel Belnap, Entailment (Princeton U.P., 1975), where the image of Chrysippus' dog regains its logical status within the context of the analysis of the disjunctive syllogism. The French example given in Louis Vax, Lexique logique (Paris: Presses Universitaires de France, 1982), p. 138 is obviously taken from Montaigne's version.

${ }^{107}$ ) D. Davidson "Rational Animals", Dialectica, 36 (1982) pp. 318-27, now in Actions and Events, ed. by E. LePore and B. P. McLaughlin (Blackwell: Oxford, 1985), quotation from p. 478. Davidson refers to Donald Weiss' paper "Professor Malcolm on animal intelligence" Philosophical Review, 84 (1975).

${ }^{108}$ ) It will be remembered that in Goethe's Faust, Mephistopheles appears as a black dog to Faust. On the issue, see the book by Barbara Allen Woods, The Devil in Dog Form, A Partial Type-Index of Devil Legends (Berkeley and Los Angeles: University of California Press, 1959), which, however, contains no indication about the dog in a trivium, and the catalogue of the Faust Museum in Knittlingen (no date of publication) p. 23 for an image. About the dogish devil, it is worth pointing out that Agrippa von Nettesheim - who seems to have been one of the historical figures who inspired the character of Faust - was said always to be accompanied by a Devil who disguised himself as a black dog, cf. the entry 'Agrippa' in P. Bayle, Dictionaire historique et critique, troisième édition, revue, corrigée et augmentée par l'auteur (Rotterdam, 1720) vol. I, p. 
$107 \mathrm{col}$ a. As for the connection between inferential capacities and magic, "that is so Mr. Holmes. You are a wizard." said Mr. James M. Dodd in "The Adventure of the Blanched Soldier", p. 1000.

${ }^{109}$ ) F. Kafka, "Investigations of a Dog", Eng. tr. by Willa and Edwin Muir in The Complete Stories ed. by N.N. Glatzer (New York: Schocken Books, 1976). An analysis of the text is provided by Lewis W. Leadbreater in his "Platonic Elements in Kafka's 'Investigations of a Dog'", Philosophy and Literature 11 (1987) pp. 104-116. Leadbreater draws a continuous line of development from the character and the technique of Socrates in the Apology and the nature of the Dog on the one hand, and the philosophical goals presented by Plato in the Phaedrus with the final aims pursued by the animal in the story.

${ }^{110}$ ) I wish to express my gratitude to Franco Basso, Kevin Berland, David H. Calhoun, Francesca Cappelletti, Victor Caston, Timothy Chappell, Tony Dale, Dorothea Frede, Tullio Gregory, Rowland Hall, Bernard Katz, Johann Klaassen, Jill Kraye, Elisabeth Leedham-Green, Paolo Mancosu, Elisabeth McGrath, Dermot Moran, Greg Restall, Alan Rudrum, Richard Sorabji, Stephen H. Voss, Germaine Warkentin and several members of various electronic lists for their comments and suggestions on several previous drafts of this paper. I would not have been able to carry on this research without the library of the Warburg Institute in London, to which I am deeply grateful for an unforgettable period of studies as a Francis Yates Fellow.

Finally, a previous, very short selection of indications taken from this article appeared in the entry "Animal Rationality" of The Oxford Dictionary of Philosophy by Simon Blackburn. 